\title{
Desertification and Population Dynamics in Nigeria
}

\author{
${ }^{1}$ Amadi D.C.A ${ }^{2}$ Nwagboso N.K; ${ }^{3}$ Uyanga J. And ${ }^{1}$ D.F. Jatau \\ ${ }^{I}$ Department of Forestry and Wildlife Management, Federal University of Technology, Yola. \\ ${ }^{2}$ Department of Geography, Federal University of Technology, Yola \\ ${ }^{3}$ Department of Building, University of Uyo, Nigeria.
}

\begin{abstract}
This paper examined the effect of desertification on population dynamics and local response to the menace in Nigeria. Data on population changes, type of energy use, house hold size, farm practices and tree plantings were collected through questionnaires from eighteen development areas as well as government agencies in Yobe State of Nigeria. The objective was to examine how desertification has resulted in diverse population changes and responses. Factor analysis was used to analyze the trends in selected environmental and population change variables. A combination of climatic factors, general increase in population and livestock pressure on land and vegetation has been identified as the chief causes of desertification. Change in population as a result of in and out migration have been dramatic coupled with diverse adjustment responses demonstrated in the development of indigenous adaptation strategies such as woven stick construction around homes, mulching and indigenous tree plantings. Environmental changes have been momentous particularly in the case of reduced water body, disappearance of vegetation cover, shifting sand dunes, increasing bare grounds and loss of biodiversity. The paper recommends the incorporation of indigenous desert environmental knowledge into government environmental conservation Programs and the need for massive tree plantings in desert prone areas and Nigeria in general. Moreover, the Federal and State departments of forestry have to be empowered with adequate revenue for massive reforestation all over the nation. Discourage dependence on wood for local energy and alternatives such as kerosene be economically provided. List of suggested anti desertification tree species has been provided since sustainable environment is concomitant with stable population.
\end{abstract}

Keywords: Desertification, Population Dynamics, Population Response.

\section{Introduction}

Concern about desertification is not entirely new. People have always been worried about the dwindling natural resource base as a result of continuous increase in population and natural resources exploitation. Today, the concern is still there and growing due to the devastating effects. (Adinna, 2001). We are now not only worried about dwindling resource base, but also agitated about different forms of environmental modification through different acts of human activities. These have produced such deleterious effects such as species extinction, accelerated erosion, pollutions, global warming, acid rains and genetic mutations. These new concerns are lucidly captured in great works of UNEP (1992); and Calestous and Ojwuang (1996). Neo-Malthusians have cautioned that we have already exploited planet earth beyond its carrying capacity and may well be heading towards the dooms day (Environmental Protection Agency, (EPA 1990). In Nigeria, and Africa in general, desertification has caused devastating long period of drought. Food situations in Africa have deteriorated seriously over last fifteen years. (Uyanga and Ekop, 2005). It is important to note that the utilization of forest resources by the rural people provides a great potential to the solution of rural poverty but at the same time constitute abuse and misuse leading to environmental degradation in the absence of regeneration programs. (Adebayo and Akindele, 2003) (Amadi,et al 2011). It is this kind of concern that gave rise to the establishment of anti-desertification projects such as the Centre for Arid Zone Studies in the University of Maiduguri in 1982 and the establishment of the Northeast Arid Zone Development Programme (NEAZDP) in Gashua in 1990. These projects were aimed at providing and developing necessary base line information to back up research in addressing the local ecological problems of desertification. The projects would encourage and stimulate appropriate and practical inputs in rural projects thereby encouraging selfsustaining rural development which will be in harmony with the farming and other land use practices. Thus, conservation and forest regeneration measures are inevitable for sustainable management of the environment since desertification is not only preventable, but reversible (UNEP1991, 1992). This is inevitable if man is to continue to live in safe, healthy and sustained environment. 


\section{Methods}

The data collected for this study includes among others respondents' settlement area, their ages, marital status, educational background, household size, source and types of energy use, rate of tree planting/removal and population changes. The study area is made up of eighteen units administratively defined as "development areas". The main source of data was through questionnaire, field observations, interviews and focus group discussions directed to community and household heads, and some officials of North East Arid Zone Development Programme (NEAZDP). The questionnaires were developed in English language, translated by the research assistants into Hausa language and administered to respondents. (Table 1.) A total of 1,779 respondents, representing 5 percent of the total population were sampled. Observations were employed side by side with interviews and discussions and they covered issues such as indigenous adaptations, agricultural practices, water use, soil erosion sites, settlement pattern, rural to urban movement, and sand dune locations. Data on the climatic conditions were collected from the meteorological station at Nguru (Tables 2, and 3). Descriptive statistics were used to summarize the conditions obtained in various areas for several variables. Factor analysis was used to establish population dynamics and dimensions of response.

\section{Results.}

The sampled population constitute of 895 males and 884 females representing 50.1 and 49.9 percents of the total sample respectively (Table 4). The ratio of male and female population in the study area shows that both sexes are adaptable to the environment and are willing to continue to live in the area if the desertification condition could be ameliorated. 37 percent of the respondents are between the ages of 20 - 30 years, 35 percent are between $30-50$ years of age. On the other hand, 19 percent of the are between the ages of $50-70$ years while only 9 percent are 70 years and above. This shows that majority of the population are composed of the active age who are potential users of most natural resources. Hence it may be concluded that the active population age demand on natural resources had contributed to desertification. In Muguram , Kaska and Wachakal some respondents had lived there between 20 to 30 years. This shows that they have contributed much to the exploitation of the environmental resource for a long period. Their continued stay also indicates their love for their home environment. It is therefore certain that any environmental conservation effort will be locally welcomed and reduce migration drastically.

\section{Environmental Change and Migration.}

It was observed that some areas have sand dunes covering above 50,000 ha. (Fig 2) Sand dunes positively influence heat and dryness, producing infertile soil and therefore induce people to move. Out migrations are highest in Machina, Bulanguwa, Wachakal and Balle (Table 5 and Fig.1). Population density varies from one locality to another. In 1991, Giedan Development Area had a population density of 26.9 persons per square kilometer. This figure increased to 36.9 in 2002 due to migration. Population Density of Nguru/Karasuwa Development Areas increased from 221.2 persons per kilometer in 1991 to 331.1 persons per kilometer over the same period. Yusufari had a population of 44,274 in 1991 increased to 55,617 in 1999 (an increase of $125.6 \%$ ) The change in population density in these areas may be explained increase in birth rate and out migrations from Machina, Bulanguwa, Wachakal and Balle.Hence. Irag (1986) observed that in most developing countries, pregnancy and birth rates are high. In the same vein, Smith (2004) submitted that subSaharan Africa remains the region with the highest levels of fertility.

\section{Factors of Response.}

Factor analysis (varimax rotation) was adopted in the data analysis and it yielded a seven dimensional solution (Table 6) each with eigenvalue greater or above one. Commensalities associated with the variables were generally high. This indicated that the variables used in the study were appropriate and relevant. The seven dimensions which accounted for $83 \%$ of total variance in the original data could be seen as composite indicators defining the basic patterns of population response.

\section{Factor 1 - Urbanization Dimension}

This factor is clearly the most important, accounting for 36.7 percent of total variance in the data set. Of the 10 variables used, 5 had high positive loadings (Table 7). These include household size, population density, annual population growth, number of new settlements and change in population. Five out of the six variables had high positive values which indicates strength and importance, while percentage house hold had high but negative value on the factor. This indicates favorable but weak association. Therefore factor 1 suggests that "Urbanization Dimension" is responsible to desertification and environmental change.

\section{Factor 2- Pressure Dimension}

This factor with an eigenvalue of 3.70919 accounts for 14.3 percent of total variance in the data set (Table 8). It has high positive loadings on out migration and percentage household, and high negative loadings 
on annual population growth, number of new settlements and change in population. Two variables - out migration and percentage house hold had high positive loadings, showing their importance, while the other three variables namely annual population growth, new settlements and change in population had high but negative loading. This shows that their presence were favorable but with weak association. Hence, there is obviously a "Pressure Dimension" capturing the push factors as population response to desertification.

\section{Factor 3 - Policy Intervention Dimension}

Four variables had high positive loading on this factor and accounted for 11.4 percent of total variance in the data set. (Table 9) These were average household size, desire for additional children, additional wives and percentage household. Again the high positive loadings of these variables indicates strength and importance Therefore factor 3 is accordingly the "Household Decision Dimension." The remaining five factors accounted for less than one quarter of the variance and were therefore not considered in the analysis. The spread of the loadings however suggest that they represent the "Policy Intervention Dimension."

\section{Conclusion}

This paper discussed population dynamics and response to desertification. It was observed that sand dunes encourage the existence of heat and dryness of bare ground which propel population move out of the environmental hash areas to more favorable locations. These phenomena provide constraints to agricultural and pastoral activities. The infertile bare soil dotted with tufted grass are exposed to incessant winds making the development areas to be sparsely populated by vegetation to the detriment of few homely areas as they experience in-migration. The study has highlighted the imperatives of indigenous environmental management knowledge in arid land management, and also provided a framework for developing a better understanding of the nexus between the environmental changes, population response and environmental policy and management.

\section{Recommendations}

There should be a long term sustainable participatory environmental improvement and resources management program. The key area that needs to be given priority in desertification prone areas is the incorporation of indigenous desert environmental knowledge into government environmental conservation program. The Federal and State Departments of Forestry need to be empowered with adequate revenue for massive reforestation program. There is need to discourage dependence on wood for local energy while alternatives fuel such as kerosene be economically and readily provided.

VI. Tables and Figures

Table 1. Population in the sampled villages

\begin{tabular}{|l|l|l|l|l|l|l|}
\hline $\begin{array}{l}\text { Development } \\
\text { Area }\end{array}$ & $\begin{array}{l}\text { Population in } \\
\text { clustered } \\
\text { villages }\end{array}$ & Male & Female & $\begin{array}{l}\text { Total } \\
\text { household }\end{array}$ & $\begin{array}{l}\text { Sampled } \\
\text { household }\end{array}$ & Percentage \\
\hline Balle & 11,635 & 63 & 58 & 2327 & 116 & 4.98 \\
\hline Bulanguwa & 11,034 & 54 & 56 & 2297 & 110 & 4.78 \\
\hline Dagona & 10,277 & 56 & 51 & 2055 & 102 & 4.96 \\
\hline Dapchi & 70,034 & 45 & 30 & 1406 & 80 & 5.68 \\
\hline Degeltura & 7,882 & 44 & 39 & 1576 & 78 & 4.94 \\
\hline Dumburi & 10,022 & 55 & 50 & 2004 & 100 & 4.99 \\
\hline Futchimiran & 4,209 & 21 & 26 & 841 & 52 & 6.18 \\
\hline Gumsa & 5,147 & 25 & 30 & 1029 & 61 & 5.92 \\
\hline Gwio kura & 16,377 & 86 & 82 & 3275 & 163 & 4.97 \\
\hline Gorgoram & 9,046 & 45 & 50 & 1809 & 100 & 5.52 \\
\hline Kanama & 6,889 & 34 & 37 & 1377 & 69 & 5.01 \\
\hline Karasuwa & 5,049 & 25 & 30 & 1009 & 60 & 5.94 \\
\hline Kaska & 13,747 & 68 & 70 & 2749 & 137 & 4.98 \\
\hline Machina & 13,081 & 65 & 70 & 2616 & 130 & 4.96 \\
\hline Muguram & 10,905 & 58 & 54 & 2181 & 119 & 5.46 \\
\hline Yunusari & 8,822 & 44 & 49 & 1764 & 95 & 5.39 \\
\hline Yusufari & 11,089 & 56 & 61 & 2218 & 111 & 5.00 \\
\hline Wachakal & 8,140 & 46 & 41 & 1628 & 96 & 5.90 \\
\hline Total & 170,385 & 895 & 884 & 34077 & 1779 & 5.22 \\
\hline
\end{tabular}

Source: National Population Commission (2001) 
Table 2 Annual Rainfalls for Some Selected Towns in Sahel Region of Yobe State. (Mm)

\begin{tabular}{|c|c|c|c|c|c|c|c|c|c|c|c|c|c|c|c|}
\hline & Year & $\mathrm{J}$ & $\mathrm{F}$ & $\mathrm{M}$ & A & $\mathrm{M}$ & $\mathrm{J}$ & $\mathrm{J}$ & $\mathrm{A}$ & $\mathrm{S}$ & $\mathrm{O}$ & $\mathrm{N}$ & $\mathrm{D}$ & Total & Mean \\
\hline \multirow[t]{5}{*}{ Nguru } & 1997 & & & & 4 & 10.3 & 22.2 & 170.0 & 129.5 & 85.8 & 12.0 & & & 434.7 & \multirow[t]{5}{*}{395.4} \\
\hline & 1998 & & & & 1 & 12.1 & 29.6 & 105.8 & 113.5 & 125.4 & 8.0 & & & 395.4 & \\
\hline & 1999 & & & & & 12.1 & 45.5 & 97.6 & 137.9 & 63.6 & 8.0 & & & 364.7 & \\
\hline & 2000 & & & & & 12.5 & 56.4 & 86.1 & 104.6 & 80.2 & 26.5 & & & 366.3 & \\
\hline & 2001 & & & & & 28.6 & 44.7 & 108.4 & 181.4 & 49.2 & 3.6 & & & 415.9 & \\
\hline \multirow[t]{5}{*}{ Kanama } & 1997 & & & & & 8.5 & 37.0 & 83.3 & 104.7 & 140.5 & 12.6 & & & 386.6 & \multirow[t]{5}{*}{381.6} \\
\hline & 1998 & & & & & 7.5 & 39.0 & 82.4 & 111.1 & 130.5 & 14.7 & & & 385.2 & \\
\hline & 1999 & & & & & 5.9 & 41.1 & 87.5 & 120.4 & 131.7 & 12.4 & & & 380.9 & \\
\hline & 2000 & & & & & 4.6 & 38.5 & 84.7 & 106 & 135.5 & 11.6 & & & 377.9 & \\
\hline & 2001 & & & & & 1.2 & 40.6 & 80.0 & 115.4 & 127.7 & 12.5 & & & 377.4 & \\
\hline \multirow[t]{5}{*}{ Geidam } & 1997 & & & & & 30.1 & 67.1 & 70.5 & 179.1 & 22.5 & 24.3 & & & 393.6 & \multirow[t]{5}{*}{425.9} \\
\hline & 1998 & & & & 1.1 & 25.5 & 44.0 & 64.7 & 208.1 & 55.3 & 8.8 & & & 407.5 & \\
\hline & 1999 & & & & & 16.8 & 25.1 & 321.2 & 211.5 & 69.0 & 15.8 & & & 659.4 & \\
\hline & 2000 & & & & & 21.6 & 27.6 & 69.1 & 126.7 & 68.0 & 22.4 & & & 335.4 & \\
\hline & 2001 & & & & & 18.6 & 24.5 & 72.4 & 130.1 & 78.2 & 10.1 & & & 333.9 & \\
\hline \multirow[t]{5}{*}{ Machina } & 1997 & & & & & 11.5 & 36.5 & 99.9 & 168.5 & 136.0 & 17.0 & & & 469.4 & \multirow[t]{5}{*}{467.7} \\
\hline & 1998 & & & & & 18.0 & 36.1 & 159.9 & 168.0 & 131.0 & 16.0 & & & 528.2 & \\
\hline & 1999 & & & & & 17.5 & 36.0 & 160.0 & 110.0 & 129.7 & 16.0 & & & 469.2 & \\
\hline & 2000 & & & & & 17.1 & 48.5 & 168.0 & 115.0 & 73.7 & 16.5 & & & 438.8 & \\
\hline & 2001 & & & & & 16.5 & 39.5 & 163.4 & 151.3 & 45.7 & 16.7 & & & 433.1 & \\
\hline \multirow[t]{5}{*}{ Kaska } & 1997 & & & & 8.2 & 17.8 & 20.0 & 104 & 150.4 & 38.1 & 6.0 & & & 250.9 & \multirow[t]{5}{*}{346.2} \\
\hline & 1998 & & & & & 17.0 & 35.5 & 174.1 & 107.2 & 38.2 & 8.7 & & & 380.7 & \\
\hline & 1999 & & & & & 15.5 & 34.4 & 175.3 & 103.1 & 37.9 & 4.3 & & & 370.6 & \\
\hline & 2000 & & & & & 15.7 & 35.4 & 174.0 & 101.5 & 35.1 & 8.0 & & & 369.7 & \\
\hline & 2001 & & & & & 16.0 & 34.1 & 170.0 & 100.6 & 34.5 & 4.0 & & & 359.2 & \\
\hline
\end{tabular}

Source NEAZDP Gashua.

Table 3 Annual Rainfall total for Nguru 1960 - 2001. (mm)

\begin{tabular}{|l|l|l|l|}
\hline Year & Total & Year & Total \\
\hline $\mathbf{1 9 6 0}$ & 514.09 & 1981 & 438.90 \\
$\mathbf{1 9 6 1}$ & 608.60 & 1982 & 409.30 \\
$\mathbf{1 9 6 2}$ & 440.70 & 1983 & 239.70 \\
$\mathbf{1 9 6 3}$ & 647.40 & 1984 & 321.50 \\
$\mathbf{1 9 6 4}$ & 536.20 & 1985 & 320.70 \\
$\mathbf{1 9 6 5}$ & 563.80 & 1986 & 309.70 \\
$\mathbf{1 9 6 6}$ & 460.8 & 1987 & 324.30 \\
$\mathbf{1 9 6 7}$ & 517.40 & 1988 & 336.10 \\
$\mathbf{1 9 6 8}$ & 489.20 & 1989 & 338.60 \\
$\mathbf{1 9 6 9}$ & 390.70 & 1990 & 418.00 \\
$\mathbf{1 9 7 0}$ & 533.40 & 1991 & 324.60 \\
$\mathbf{1 9 7 1}$ & 460.50 & 1992 & 415.10 \\
$\mathbf{1 9 7 2}$ & 247.60 & 1993 & 335.60 \\
$\mathbf{1 9 7 3}$ & 258.90 & 1994 & 428.80 \\
$\mathbf{1 9 7 4}$ & 601.80 & 1995 & 370.60 \\
$\mathbf{1 9 7 5}$ & 558.30 & 1996 & 312.90 \\
$\mathbf{1 9 7 6}$ & 430.00 & 1997 & 434.70 \\
$\mathbf{1 9 7 7}$ & 509.00 & 1998 & 395.40 \\
$\mathbf{1 9 7 8}$ & 496.00 & 1999 & 364.70 \\
$\mathbf{1 9 7 9}$ & 587.80 & 2000 & 366.30 \\
\hline $\mathbf{1 9 8 0}$ & 339,60 & 2001 & 415.90 \\
\hline
\end{tabular}


Table 4. Characteristics of the population

\begin{tabular}{|c|c|c|c|c|c|c|c|c|c|c|c|c|c|}
\hline \multirow{2}{*}{$\begin{array}{l}\text { Settlement } \\
\text { s }\end{array}$} & \multicolumn{2}{|c|}{ Sex } & \multicolumn{5}{|c|}{ Length of Stay } & \multicolumn{3}{|c|}{ Age } & \multicolumn{3}{|c|}{ Religion } \\
\hline & $\mathrm{M}$ & $\mathrm{F}$ & $1-10$ & $\begin{array}{l}10- \\
20\end{array}$ & $20+$ & $\begin{array}{l}\text { Since } \\
\text { Birth }\end{array}$ & $\begin{array}{l}20- \\
30\end{array}$ & $\begin{array}{l}30- \\
50\end{array}$ & $\begin{array}{l}50- \\
70\end{array}$ & $70+$ & Islam & Christ & Trad \\
\hline Muguram & 55 & 54 & 37 & 28 & 22 & 22 & 30 & 47 & 20 & 12 & 100 & 9 & 0 \\
\hline Kaska & 68 & 69 & 55 & 30 & 30 & 42 & 47 & 22 & 31 & 37 & 136 & 1 & 0 \\
\hline Wachakal & 54 & 46 & 6 & 16 & 24 & 14 & 68 & 21 & 9 & 2 & 100 & 0 & 0 \\
\hline Yunusari & 44 & 44 & 35 & 35 & 10 & 8 & 34 & 18 & 16 & 20 & 70 & 18 & 0 \\
\hline Yusufari & 56 & 64 & 30 & 28 & 48 & 30 & 37 & 44 & 29 & 0 & 105 & 5 & 0 \\
\hline Bulangua & 54 & 56 & 30 & 28 & 22 & 30 & 32 & 44 & 31 & 3 & 100 & 10 & 0 \\
\hline Dapchi & 40 & 30 & 30 & 17 & 15 & 8 & 21 & 17 & 16 & 16 & 64 & 60 & 0 \\
\hline Dumburi & 50 & 40 & 30 & 8 & 21 & 41 & 31 & 61 & 5 & 3 & 89 & 11 & 0 \\
\hline $\begin{array}{l}\text { Gwio } \\
\text { Kura }\end{array}$ & 81 & 82 & 40 & 51 & 27 & 45 & 63 & 72 & 23 & 5 & 160 & 3 & 0 \\
\hline Kanama & 34 & 35 & 35 & 10 & 14 & 10 & 27 & 24 & 18 & 0 & 54 & 15 & 0 \\
\hline
\end{tabular}

Table 5 Migrations into and out of the study area.

\begin{tabular}{lcc}
\hline \multicolumn{1}{c}{ In Migration } & Out Migration \\
\hline Balle & 12 & 150 \\
Bulanguwa & 54 & 56 \\
Dagona & 13 & 59 \\
Dapchi & 30 & 40 \\
Degeltura & 10 & 6 \\
Dumburi & 40 & 60 \\
Futchimiran & 9 & 38 \\
Gumsa & 8 & 36 \\
Gwio Kura & 81 & 82 \\
Gongoram & 6 & 37 \\
Kanama & 25 & 44 \\
Karasuwa & 3 & 123 \\
Kaska & 76 & 61 \\
Machina & 11 & 140 \\
Muguram & 53 & 56 \\
Yunusari & 36 & 52 \\
Yusufari & 43 & 67 \\
Wachakal & 48 & 5 \\
\hline TOTAL & 558 & 1154 \\
\hline
\end{tabular}

Table 6 Rotated Factor Matrix

\begin{tabular}{|c|c|c|c|c|c|c|c|c|}
\hline Variable & 1 & 2 & 3 & 4 & 5 & 6 & 7 & Communality \\
\hline $\mathrm{Y}_{1}$ & -.29785 & 0.91389 & 0.39420 & 0.2748 & -0.11955 & .16370 & .23683 & .087071 \\
\hline $\mathrm{Y}_{2}$ & .32929 & 0.19892 & 0.44507 & 0.09305 & 0.09345 & -.01241 & .12199 & .72303 \\
\hline $\mathrm{Y}_{3}$ & .68890 & 0.35723 & 0.85171 & 0.26615 & 0.00033 & .00550 & .17818 & .82851 \\
\hline $\mathrm{Y}_{4}$ & .12996 & -.11126 & 0.58584 & 0.24048 & 0.06462 & .02720 & -.03790 & .65607 \\
\hline $\mathrm{Y}_{5}$ & -.42658 & 0.02150 & 0.56094 & 0.07467 & -0.12391 & .12076 & .26484 & .80576 \\
\hline $\mathrm{Y}_{6}$ & -.85413 & 0.68727 & 0.54467 & 0.27296 & -0.06063 & .07694 & -.18973 & .91712 \\
\hline $\mathrm{Y}_{7}$ & .86827 & 0.08950 & 0.16184 & 0.14049 & 0.21462 & .05712 & -.16323 & .88380 \\
\hline $\mathrm{Y}_{\mathrm{s}}$ & .92934 & -.80545 & 0.17329 & 0.15246 & 0.09766 & .02278 & -.03193 & .92801 \\
\hline$Y_{9}$ & .73948 & -.86543 & 0.32582 & 0.03807 & -0.07843 & .0409 & .00204 & .88276 \\
\hline$Y_{10}$ & .94000 & -.60722 & -.30881 & 0.10069 & 0.31795 & -.07194 & -.09507 & .93001 \\
\hline Eigenvalue & 9.53931 & 3.70919 & 2.96268 & 1.10760 & 1.31645 & 1.22648 & 1.06547 & \\
\hline$\%$ Variance & 96.7 & 14.3 & 11.4 & 6.6 & 5.1 & 4.7 & 4.1 & \\
\hline $\begin{array}{l}\text { Commulative } \\
\text { Percent. }\end{array}$ & 36.7 & 51.0 & 62.4 & 68.9 & 74.0 & 78.7 & 82.8 & \\
\hline
\end{tabular}

Source Data Analysis. 
Table 7 Significant Variable Loadings on Factor 1

\begin{tabular}{lll}
\hline Factor Code & Variable & Rotated Loadings \\
\hline Y3 & House hold Size & 0.68890 \\
Y6 & Percentage House hold & -0.85413 \\
Y7 & Population Density & 0.86827 \\
Y8 & Annual Population Growth & 0.92934 \\
Y9 & New Settlemnets & 0.73948 \\
\hline Y10 & Change in Population & 0,94000 \\
\hline \multicolumn{3}{c}{ Source: Data Analysis }
\end{tabular}

Table 8 Significant Factor Loadings for Factor 11

\begin{tabular}{lll}
\hline Code & Variable & Rotated Loadings \\
\hline Y1 & Out migration & 0.91389 \\
Y6 & Percentage House hold & 0.68727 \\
Y8 & Annual Population Growth & -0.80545 \\
Y9 & New Settlements & -0.6543 \\
\hline Y10 & Change in Population & -0.60722 \\
\hline
\end{tabular}

Source: Data Analysis

Table 9 Significant Variable Loadings on Factor 3

\begin{tabular}{lll}
\hline Code & Variable & Rotated Loadings \\
Y3 & House hold Size & 0.85171 \\
Y4 & Desire for Children & 0.58584 \\
Y5 & Desire for Wives & 0.56094 \\
Y6 & Percentage Household & 0.54467 \\
\hline
\end{tabular}

Interesting anti-desertification plants

Acacia species: acacia

Acca sellowiana : feijao, pineapple guava

Agave Americana: century plant

Amaranthus spp.: amaranth

Annona cherimola : cherimoya

Annona muricata : guanabana, soursop, graviola

Asimina triloba : pawpaw

Caragana microphylla: littleleaf peashrub

Caryopteris $x$ clandonensis : Blue beard / Blue mist

Cleome gynandra: African cabbage, cat's whiskers

Crocus sativus : saffron crocus

Cydonia oblonga : quice, membrillo

Cyphomandra betacea : tomato tree

Dacryodes edulis : safou or butterfruit

Garcinia lmivingstonei : imbe

Gleditsia triacanthos : honey locust

Hippophae rhamnoides : sea buckthorn

Hylocereus undatus : dragonfruit

INTA Sequia common bean

Ipomoea batatas : sweet potato

Irvingia gabonensis : Dika tree

Jatropha curcas : Barbados nut, Physic nut

Linum usitatissimum : Flax

Lupinus luteus, L. hispanicus and L. cosentinii: lupins
Mesembryanthemum acinaciforme : Fig-Marigold, Giant Pigface, Hottentot Fig

Moringa oleifera: Moringa

Morus spp. : mulberry

Oenothera speciosa: Mexican evening primrose

(invasive ground cover)

Opuntia ficus-indica: prickly pear cactus

Oxytenanthera abyssinica: drought-resistant bamboo

Panicum virgatum : switchgrass

Portulacaria afra : spekboom, elephant bush

Prosopis cineraria

Rheum palaestinum: Desert rhubarb

Ricinus communis: castor plant

Sesamum indicum - sesame

Sclerocarya birrea: marula

Sesbania rostrata

Sesbania sesban

Simmondsia chinensis: jojoba

Solanum scabrum: African nightshade

Strychnos spinosa: monkey orange

Tephrosia candida

Tylosema esculentum: marama

Vitex agnus-castus: chaste tree 


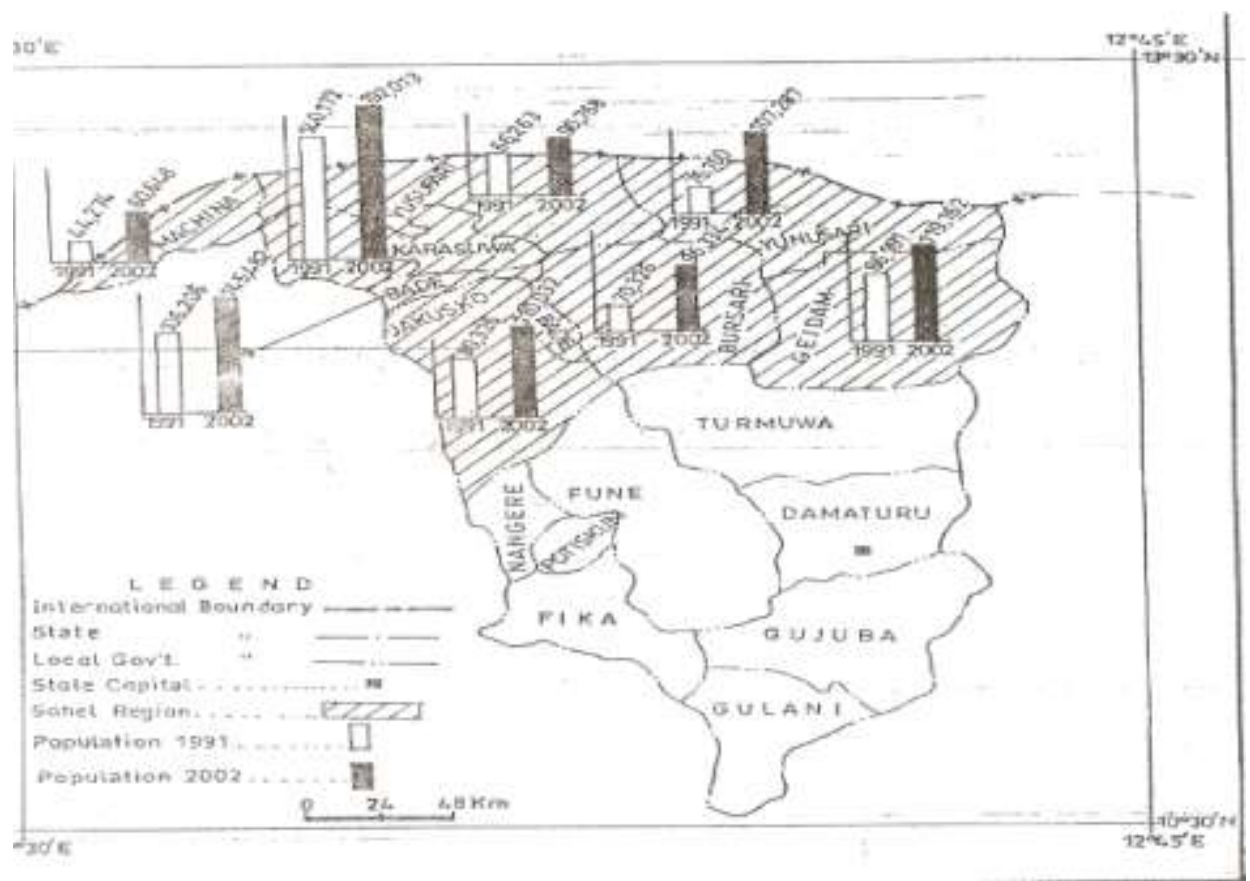

Fig 1 Population Density Per $\mathrm{Km}^{2}$ In the Development Area in 2002

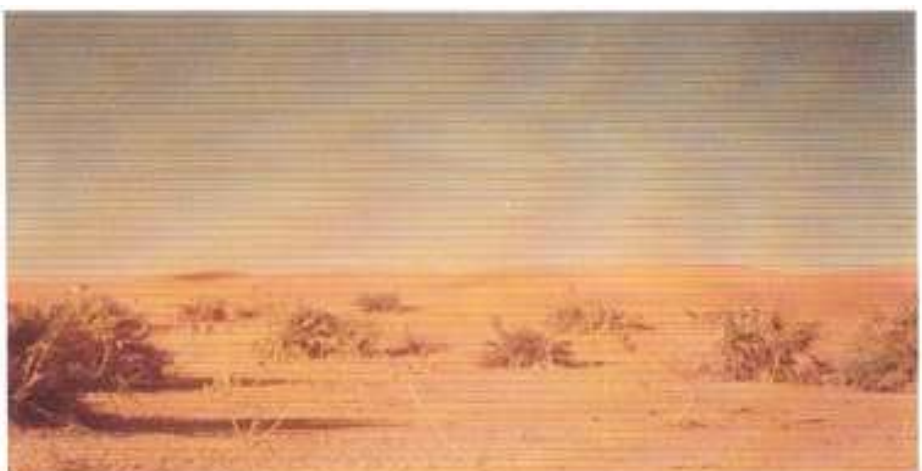

Fig. 2 Extensive Bare Ground North-East of Tulo-Tulo Village, Yusufari L.G.A., Yobe State

\section{References}

[1] Adebayo A.G. and Akindele S.O. (2003) Appraisal of Forest Resources Utilization and Its Impact on Rural Household Poverty in Kwara State, Nigeria.

[2] The Nigeria Journal of Forestry, Forestry Association of Nigeria Vol. 33 Nos. 1 and 2 Adinna, E. N. (2001). "Environmental Hazards and Management” Snaap Press Enugu.

[3] Amadi, D.C.A., Nwagboso, N.K., Kwaga, B.T. and Akosim C. Human Coping Strategies to Desertification in Yobe State, Nigeria. Animal Research International 8(3) 1439-1444. 2011.

[4] Calestous, Juma and J. B. Ojwang (1996). In Land we Trust Initiatives Publishers Nairobi Kenya.

[5] EPA (1990). The State of the Environment, UNICAF, UNEP Publisher New York.

[6] Irag, P. (1986) Rural Development and Developing Countries, An Interdisciplinary Approach. Canada, Alger Press Ltd

[7] NEST (1991) Nigeria Threatened Environment. Nigerias Environmental Study Action/Group. Ibadan.

[8] Oguntoyinbo, J. S. (1991) "Towards a Better Understanding of Drought Phenomenon in West Africa" in Oguntoyinbo, J. S. et al eds in Meteorological Hazards and Development. NMS Lagos. PP163 - 166

[9] Smith, J.O. (2004) Contradictions in Nigeria's Fertility Transition: The Burden of Having People. In Population and Development Review vol. 30 No. 2 New York

[10] UNEP (1991) Status of Desertification and Implementation of UN Plan of Action to Combat Desertification UNEP Nairobi

[11] UNEP (1992) World Environment, Chapman and Hall London Uyanga J, and Ekop O.B. (2005) Towards Sustainable Livelihood in Drought - Prone

[12] Areas of Africa. In Uyanga J; Galtima M and Ono M. (Eds ) (2005) Towards Sustainable Environmental Management. Yola, Paraclete Publishers. pp $24-31$.

[13] Wade, N. (1994). "Sahelian Drought: No Victory for Western Aid,"Science, Vol. 19, No 4. pp 36 - 39.

[14] Whitemore, M. (1990). "Land Resource Depletion" in Pearl M. C. ed Conservation for $21^{\text {st }}$ Century Oxford London. 